\title{
The Effect of Cooperative Learning on Mathematics Learning Outcomes Viewed from Students' Learning Motivation
}

\author{
Firdha Razak \\ Department of Mathematics Education, STKIP Andi Matappa Pangkep \\ Corresponding author: firdarazak@yahoo.com
}

\begin{abstract}
This experimental research was aimed to reveal the effect of cooperative learning models viewed from the level of learning motivation on students' learning achievement on mathematics. The data were analyzed using the Two-W ay ANOV A. The conclusions of this study are: (1) there were effects of interaction between cooperative learning models (TPS and NHT) and learning motivation on mathematics learning achievement, (2) the mathematics learning acbievement of students with bigh level of learning motivation who were taught using TPS model is higher than those who were taught using NHT, and (3) the mathematics learning achievement of the students with low level learning motivation who were taught using TPS model is insignificantly different than those who were taught using NHT.
\end{abstract}

Keywords: cooperative learning, students' achievement, students' motivation

\begin{abstract}
Abstrak. Tujuan penelitian eksperimen ini untuk menguji pengarub model pembelajaran kooperatif terhadap hasil belajar matematika ditinjau dari tingkat motivasi belajar siswa. Penelitian ini dilaksanakan di Kabupaten Pangkep dengan populasi siswa kelas X SMK Negeri di Bungoro. Sampel dalam penelitian ini adalah kelas di SMK Negeri 1 dan SMK Negeri 2 Bungoro yang diperoleh dengan teknik cluster random sampling. Data dianalisis menggunakan analisis varian dua jalur. Hasil penelitian ini adalab: (1) ada pengarub interaksi antara model pembelajaran kooperatif tipe TPS dengan model pembelajaran kooperatif tipe NHT dan motivasi belajar terhadap hasil belajar matematika (2) hasil belajar matematika siswa yang diajar melalui model pembelajaran kooperatif tipe TPS lebih tinggi dari pada model pembelajaran kooperatif tipe NHT untuk siswa bermotivasi tinggi (3) basil belajar matematika siswa yang diberikan pembelajaran menggunakan model kooperatif tipe TPS tidak berbeda dengan model pembelajaran kooperatif tipe NHT untuk siswa yang memiliki motivasi rendah.
\end{abstract}

Kata Kunci: motivasi belajar, pembelajaran kooperatif, prestasi belajar

\section{Introduction}

In the 2012/2013 National Examination fail rate for senior high school (SMA/MA) in South Sulawesi province, Pangkep district was ranked third which indicated its low outcomes of students' learning activities. In addition, the district was also ranked first for the fail rate of its vocational high schools. In fact, the average score for mathematics in the 2012/2013 national exam was the lowest compared to other subjects. It can be identified from the average scores of two vocational high schools in 
Pangkep district, namely SMK Negeri 1 Bungoro and SMK Negeri 2 Bungoro. The yields of these two schools, respectively, for Bahasa Indonesia were 5.75 and 5.37; English were 5.60 and 5.19; and Mathematics were 4.11 and 4.20.

A mathematics teacher has to be incapable in elaborating the concepts in addition to teach mathematics by constructing amusing learning process atmosphere, as well to encourage students' motivation to be actively involved in the class. According to Sardiman (2001: 73) motivation is considered as the whole student's driving force leads to learning activities, which ensures the learning continuity and gives direction to the learning activities so that the intended purpose of the subjects can be achieved. In other words, students' internal motivation is capable to stimulate the students to carry out learning activities to reach their goals. Motivation definitely supports students in mastering the materials and in consequence, students' mathematics learning outcomes also increase. One of student's managements to motivate their learning activities is cooperative learning model. In this study, researcher implemented the model of cooperative learning particularly Think Pair Share and Numbered Heads Together type in mathematics learning activities.

Cooperative learning model of Think Pair Share type is an interesting learning model since it encourages students to work cooperatively in group and to be able to work individually at the same time. The phases of Think Pair Share include Thinking, Pairing, and Sharing which absolutely promote the development of students' creativity in learning mathematics that are expected to encourage the students to be more creative, rapid, and precise in solving mathematical problems. TPS is expected to provide activities and interaction between proficient students and less intelligent students in the classroom. Therefore, they can help each other in solving problems and in mastering the subject (Lie, 2005:57). Cooperative learning model of Numbered Heads Together (NHT) is one of cooperative learning technique which promotes the activities of digging up, analyzing, and reporting the information derived from various sources and eventually presenting the result. In the process, each student in the group will be numbered and the teacher will assign a task for the groups before picking up a number to report the result. It is expected that the model can foster student's responsibility, particularly as a member of a group (Lie, 2005:60).

Based on the explanation of research background, several hypotheses propounded in this study were formulated as follows:

1. There were interactions between cooperative learning model and students' motivation on students' mathematics learning achievement.

2. Students with high motivation who were taught with cooperative learning model of Think Pair Share (TPS) were indicated to obtain higher mathematics learning outcomes compared to students learning with cooperative learning model of Numbered Heads Together (NHT).

3. Students with low motivation who were taught with cooperative learning model of Think Pair Share (TPS) were indicated to obtain lower mathematics learning outcomes compared to students learning with cooperative learning model of Numbered Heads Together (NHT).

Furthermore, the objectives of the study were:

1. To reveal the interaction between cooperative learning models of Think Pair Share (TPS) and Numbered Heads Together (NHT) with learning activities motivation viewed from mathematics learning outcomes.

2. To evaluate the mathematics learning outcomes of two groups of high motivation students: first, who were engaged in cooperative learning model of Think Pair Share 
(TPS), and second, who were engaged in cooperative learning model of Numbered Heads Together (NHT).

3. To evaluate the mathematics learning outcomes of two groups of low motivation students: first, who were engaged in cooperative learning model of Think Pair Share (TPS), and second, who were engaged in cooperative learning model of Numbered Heads Together (NHT).

\section{Research Methods}

The study was quantitative research with experimental design by carrying out treatment in 2 (two) state vocational high schools in Bungoro, namely, SMK Negeri 1 Bungoro and SMK Negeri 2 Bungoro. Treatment implemented in the first group was mathematics learning with cooperative learning model of Think Pair Share (TPS) technique and the second group was mathematics learning with cooperative model of Numbered Heads Together (NHT) technique. This study was a quasy experiment since there were other uncontrollable variables.

The population of the study was the students of tenth grade in State Vocational High Schools in Bungoro district at the academic year of 2013/2014 under the consideration that all vocational schools in bungoro had been using the new Indonesian curriculum (K-13) and the average learning achievement in each school are not much different. The sampling method was cluster random sampling. The samples were determined by using a technique with phases as follows:

1. Two out of three state schools in Bungoro district were selected randomly. The result was SMK Negeri 1 Bungoro and SMK Negeri 2 Bungoro.

2. Cluster sampling was conducted to opt up the observed classes. SMK Negeri 1 Bungoro consists of 13 homogenous classes and SMK Negeri 2 Bungoro consisted of 12 homogenous classes. These classes were randomly selected to determine the samples as the first group and the second one. Each class given different treatment namely, TPS was implemented in the first group consisted of 30 students while NHT was implemented in the second group consisted of 32 students.

Research design used in this study was Posttest Only Control Design. The variables in this study were Think-Pair-Share (TPS) and Numbered Heads Together (NHT) learning model as independent variables, students learning outcomes as dependant variable, and motivations as control. Instruments involved in this study were questionnaire of learning motivation and posttest. Data was analyzed by using $2 \times 2$ factorial design.

Table 1. Analysis Design on Mathematics Learning Outcomes

\begin{tabular}{|c|c|c|c|}
\hline & & \multicolumn{2}{|c|}{$\mathrm{A}$} \\
\hline & & $A_{1}$ & $\mathrm{~A}_{2}$ \\
\hline \multirow{2}{*}{ B } & $\mathrm{B}_{1}$ & $A_{1} B_{1}$ & $A_{2} B_{1}$ \\
\hline & $\mathrm{B}_{2}$ & $A_{1} B_{2}$ & $\mathrm{~A}_{2} \mathrm{~B}_{2}$ \\
\hline
\end{tabular}

Description:

A $=$ Cooperative learning model 


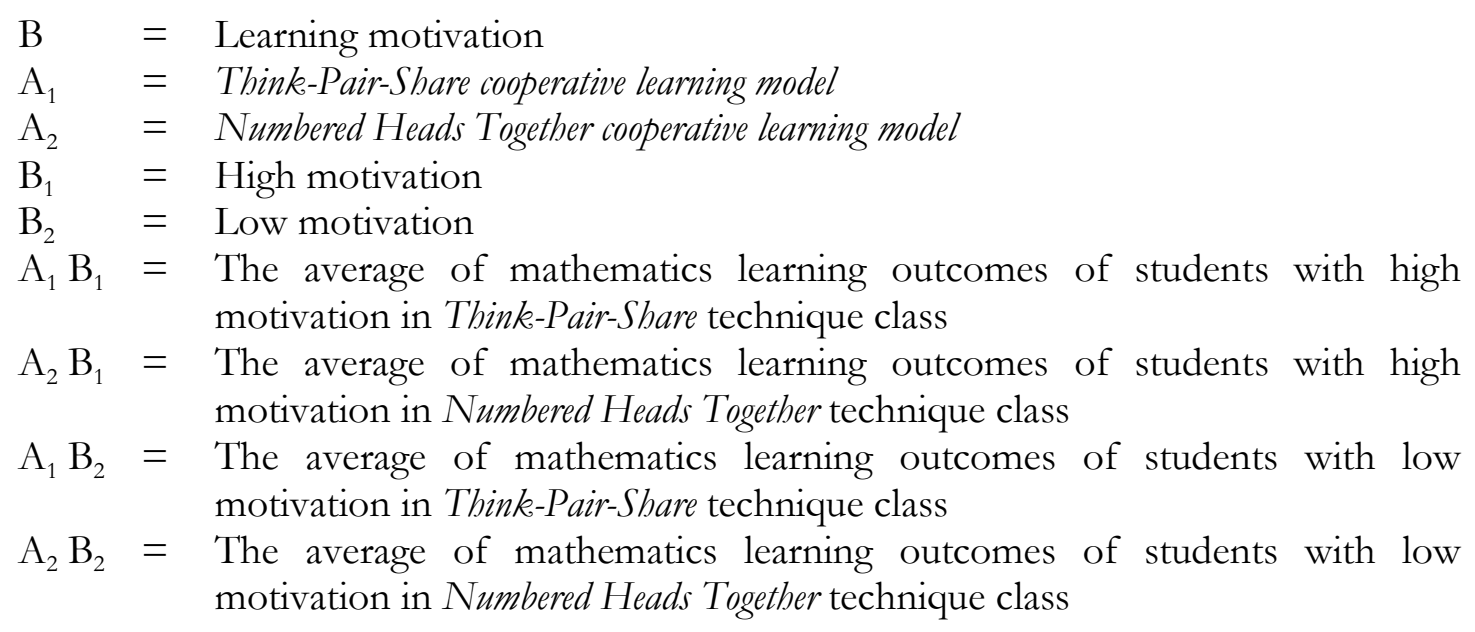

\section{Results and Discussion}

Hypothesis testing was carried out by using Two-Way ANOVA. In advance, examination on analysis requirements which was assessment on random error unit of homogenous variances was done. The test of homogeneity of variances is as follows.

Table 2. Test of Homogenity of Variances

\begin{tabular}{rccc}
\hline \multicolumn{4}{c}{ Test of Homogeneity of Variances } \\
\hline Y & & \\
\hline Levene Statistic & df1 & df2 & Sig. \\
2.508 & 3 & 30 & .078 \\
\hline
\end{tabular}

Based on Table 2, it can be withdrawn that p-value $=0.078>\alpha=0.05$. Thereby inferential, the population variances of the four groups were homogeneous.

Subsequently, hypothesis testing using two-way analysis of variance (ANOVA) was carried out. The result of the assessment of two-way analysis of variance is presented in Table 3 below.

Table 3. Test of Effect between Subjects

\begin{tabular}{cccccc}
\hline Source & $\begin{array}{c}\text { Sum of Squares of } \\
\text { Type I }\end{array}$ & Df & $\begin{array}{c}\text { Mean } \\
\text { Square }\end{array}$ & F & Sig. \\
\hline $\begin{array}{c}\text { Corrected } \\
\text { Model }\end{array}$ & 6515.007 & 3 & 2171.669 & 35.972 & .000 \\
Intercept & 165481.882 & 1 & 165481.882 & 2741.111 & .000 \\
$\mathbf{A}$ & 6223.529 & 1 & 6223.529 & 103.089 & .000 \\
$\mathbf{B}$ & 226.118 & 1 & 226.118 & 3.746 & .062 \\
$\mathbf{A}^{* \mathbf{B}}$ & 65.359 & 1 & 65.359 & 1.083 & .306 \\
Error & 1811.111 & 30 & 60.370 & & \\
Total & 173808.000 & 34 & & & \\
Corrected & 8326.118 & 33 & & & \\
Total & & & & &
\end{tabular}

Where: A = Learning Model, $\mathrm{B}=$ Motivation 
Based on analysis of ANAVA, it can be explicated that: $p-$ value $=0.306>0.05=\alpha$, therefore $\mathrm{H}_{0}$ was accepted which means there was no interaction effect between cooperative learning model and learning motivation on mathematics learning outcomes.

Based on the first hypothesis testing regarding with the effect of interaction between cooperative learning model and learning motivation on students' mathematics learning outcomes, it was stated that $\mathrm{H}_{0}$ was accepted which means there is no interaction effect between learning model and learning motivation on mathematics learning outcomes. In this study, the absence of interaction did not necessarily imply there was no correlation between the treatments. In fact, student's self-motivation has supported student's eagerness to perform well in each cooperative learning activity. Similar to Robinson in Suyadi (2008), learning motivation is an attitude that constructs the student to do, direct, and get spirit of achievement.

To test hypothesis two and three, therefore multiple comparison tests between columns were required.

Table 4. Result of Mean Comparison Test between Columns

\begin{tabular}{cccc}
\hline Comparison & T value & T table & Decision \\
\hline$A_{1} B_{1}$ vs $A_{2} B_{1}$ & $\mathbf{2 . 8 0 9}$ & 2.131 & Reject $\mathrm{H}_{0}$ \\
$A_{1} B_{2}$ vs $A_{2} B_{2}$ & 0.528 & 2.131 & Accept $\mathrm{H}_{0}$ \\
\hline
\end{tabular}

From the data in Table 4, it can be concluded that:

1. In comparison test-1, the value of $t_{\text {value }}=2.809>2.131=t_{\text {table }}$, therefore, $H_{0}$ was rejected. It can be concluded that the students with high motivation in class with the treatment of Think Pair Share (TPS) technique was evidenced to possess higher mathematics learning outcomes than those in class with the treatment of Numbered Heads Together (NHT) technique.

2. In comparison test-2, the value of $t_{\text {value }}=0.528<2.131=t_{\text {table }}$ therefore, $\mathrm{H}_{0}$ was accepted. It can be concluded that the students with low motivation in class with the treatment of Think Pair Share (TPS) technique was insignificantly different in learning achievement than those in class with the treatment of Numbered Heads Together (NHT) technique.

In the second hypothesis testing, it was stated that $\mathrm{H}_{0}$ was rejected which means that students with high motivation who were engaged in class of Think Pair Share (TPS) technique obtained higher mathematics learning outcomes than those who were engaged in class of Numbered Heads Togeher (NHT) technique. This empirical finding is confirmed by Nasikhah (2011) who declares cooperative model of Think Pair Share generates better mathematics learning achievement compare to Numbered Heads Together (NHT). It is also similar to Verowita (2012) who states the result of students' concept understanding test with TPS learning model is better compared to those with conventional learning model. It is presumed that in cooperative learning model of Think Pair Share (TPS), the group merely consists of two students, hence, student has an opportunity to think individually before sharing with the partner. After the student has solution, they team up with the partner to exchange their solution to obtain the best solution. In this learning model, students definitely build up their knowledge through the provided material. While Numbered Heads Together (NHT) technique requires numbering card with 4-5 students in discussion which leads to ineffective learning process. Some members might not be actively involved in discussion. In consequence, not all members have really understood the discussed material. The achievement of students' learning outcomes in these two techniques was resulted from the excellence of each technique and their characteristics 
which are capable to trigger students' learning outcomes supported by high learning motivation. In accordance to data analysis, it seems that Think Pare Share is more effective than Numbered Heads Together technique.

In the third hypothesis testing, it was stated that $\mathrm{H}_{0}$ was accepted which means that the mathematics learning outcomes of students with low motivation who were engaged in the class of cooperative learning with Think Pair Share (TPS) technique, were insignificantly different in learning achievement compared to those who were engaged in the class of cooperative learning of Numbered Heads Together (NHT) technique.

Although there are no significant differences, both of these models can be applied in mathematics because of the advantages of each type and characteristics of those able to give motivation to students that affect student learning outcomes. It is supported by Nur (2004) states that the cooperative learning model can motivate all students, utilizing all social energy of students, and mutual responsibility. This is reinforced by the opinions of Hulten and De Vries (in Slavin, 1995) who found that by making cooperative learning group members excited. These results are relevant to the theory from Vygotsky (Nur, 2004) regarding the implementation of cooperative learning, students' interaction with adults or peers who are better able to be effective in developing growth within the Zone Proximal Development (ZPD).

Analysis on theoretical review indicated that cooperative learning model of Think Pair Share (TPS) and Numbered Heads Together (NHT) are the technique of cooperative learning, although their differential scenario or syntax of learning activities also resulted diverse effect on student's learning outcomes, in this study. In the technique of cooperative learning model of Numbered Heads Together (NHT) that uses a numbered card consisting of 4-5 people, total member of the group in these discussions leads to ineffective learning activities since some students prefer to be less involved during the activities and rely on other viable members, in consequence, not all members have really understood the discussed material. In contrast, in the cooperative learning model of Think Pair Share (TPS) technique, the group merely consists of two students with the phases of Think (think individually) in which students are encouraged to think by themselves and Pair in which they work on as a team. Once the student obtains a solution, they team up with other students to exchange ideas in order to obtain the best solution from both. In addition, each team will present the produced solution and the results will be discussed with other pairs in the class. This phase is known as Sharing. In this technique, the students actually build up knowledge through problem or the provided material.

\section{Conclusion}

Based on the study results it can be concluded that 1) there were no interactions between cooperative learning model and learning motivation on mathematics learning outcomes. The result of hypothesis testing showed statistic value of $\mathrm{p}-$ value $=0.306$ $>0.05=\alpha$. It means that $\mathrm{H}_{0}$ was accepted; 2) mathematics learning outcomes of students with high motivation and engaged in cooperative learning class with Think Pair Share (TPS) technique were evidenced to be higher compared to those engaged in cooperative learning class with Numbered Heads Together (NHT) technique. This result was based on comparison test 1 in which the value of $\mathrm{t}_{\text {value }}=2.809>2.131=\mathrm{t}_{\text {table }}$, thus, $\mathrm{H}_{0}$ was rejected; and 3) mathematics learning outcomes of students with low motivation and engaged in cooperative learning class with Think Pair Share (TPS) technique were insignificantly different with those engaged in cooperative learning class with Numbered Heads Together (NHT) technique. This result was based on comparison test- 2 in which the value of $\mathrm{t}_{\text {value }}=0.528<2.131=\mathrm{t}_{\text {table, }}$, therefore, $\mathrm{H}_{0}$ was accepted. 


\section{Bibliography}

Dalud Daeka. (2014). Eksperimentasi Model Pembelajaran Kooperatif Tipe Numbered Head Together (NHT) dan Think Pair Share (TPS) Ditinjan dari Kreativitas Belajar Siswa Kelas VII SMP Negeri di Kabupatem Pacitan. Jurnal Elektronik Pembelajaran Matematika. Vol.2, No.3, hal 301-311.

Ilyasari, Astia. 2013. Pengaruh Model Pembelajaran Kooperatif Tipe NHT Terhadap Pemahaman Konsep Matematis Siswa. Jurnal Penddikan Matematika.No 7. Vol 7.

Lie, Anita. (2005). Cooperatif Learning: mempraktikkan Cooperatif Learning di RuangRuang Kelas. Jakarta: Grasindo

Nur, M. (2004). Strategi-strategi Belajar. Surabaya: University Press. Universitas Negeri Surabaya.

Nasikhah, Q. (2011). Eksperimentasi Model Pembelajaran TPS (think Pair Share) dan NHT (Numbered Head Together) terhadap Prestasi Belajar Matematika Ditinjan Dari Kemampuan Komunikasi Matematika Siswa Kelas VII SMP SE-Kecamatan Purwarejo. Thesis. Prodi Pendidikan Matematika FKIP Universitas Muhammadiyah Purworejo.

Sardiman. A.M. (2001). Interaksi dan Motivasi Belajar Mengajar. Jakarta: PT. Raja Grafindo Persada.

Sardjoko, T.(2012). Efektivitas Model Pembelajaran Kooperatif tipe Numbered Head Together dan Group Investigation pada Prestasi Belajar Matematika di Tinjan dari Motivasi Berprestasi Siswa. Thesis. Surakarta: Program Pasca Sarjana Universitas Sebelas Maret Surakarta.

Slavin, Robert E (1995). Cooperative Learning Theory, Research and Practice. Massachusett, USA: Allymand \& Bacon.

Suyadi. (2008). Pengaruh Pembelajaran Penemuan Fisika pada Kinematika Gerak Lurus Melalui Model Eksperimen Dan Demonstrasi Terbadap Prestasi Belajar Ditinjan dari Motivasi. Surakarta: UNS.

Verowita, W. (2012). Pengaruh Penerapan Model Pembelajaran Kooperatif Tipe Think pair share Terhadap Pemahaman Konsep dalam Pembelajaran Matematika. Jurnal Pendidikan Matematika, 1(1). 